\title{
Insulin-like Growth Factor-I Improves Glucose and Lipid Metabolism in Type 2 Diabetes Mellitus
}

Peter D. Zenobi, Silvia E. Jaeggi-Groisman, Walter F. Riesen, ${ }^{\star}$ Michael E. Roder, ${ }^{\star}$ and E. Rudolf Froesch

Division of Endocrinology and Metabolism, Department of Internal Medicine, University Hospital, 8091 Zurich, Switzerland;

*Institute for Clinical Chemistry and Hematology, State Hospital, 9000 St. Gallen, Switzerland; and

${ }^{\ddagger}$ Steno Diabetes Center, 2820 Gentofte, Denmark

\begin{abstract}
Hyperglycemia, hyperinsulinemia, and insulin resistance cause vascular disease in type 2 diabetes mellitus. Dietary treatment alone often fails and oral drugs or insulin enhance hyperinsulinemia. In previous studies, an intravenous bolus of recombinant human insulin-like growth factor-I (rhIGF-I) caused normoglycemia in insulin-resistant diabetics whereas rhIGF-I infusions lowered insulin and lipid levels in healthy humans, suggesting that rhIGF-I is effective in insulin-resistant states. Thus, eight type 2 diabetics on a diet received on five treatment days subcutaneous rhIGF-I $(2 \times 120 \mu \mathrm{g} / \mathrm{kg})$ after five control days. Fasting and postprandial glucose, insulin, C-peptide, proinsulin, glucagon, triglyceride, insulin-like growth factor-I and -II, and growth hormone levels were determined.
\end{abstract}

RhIGF-I administration increased total IGF-I serum levels 5.3-fold above control. During the control period mean $( \pm \mathrm{SD})$ fasting glucose, insulin, $\mathrm{C}$-peptide, and total triglyceride levels were $11.0 \pm 4.3 \mathrm{mmol} / \mathrm{liter}, 108 \pm 50 \mathrm{pmol} / \mathrm{liter}, 793 \pm 250 \mathrm{pmol} /$ liter, and 3.1 $\pm 2.7 \mathrm{mmol} / \mathrm{liter}$, respectively, and decreased during treatment to a nadir of $6.6 \pm 2.5 \mathrm{mmol} / \mathrm{liter}, 47 \pm 18 \mathrm{pmol} /$ liter, 311 $\pm 165 \mathrm{pmol} / \mathrm{liter}$, and $1.6 \pm 0.8 \mathrm{mmol} / \mathrm{liter}(P<0.01)$, respectively. Postprandial areas under the glucose, insulin, and C-peptide curve decreased to $77 \pm 13(P<0.02), 52 \pm 11$, and $60 \pm 9 \%(P<0.01)$ of control, respectively. RhIGF-I decreased the proinsulin/insulin ratio whereas glucagon levels remained unchanged. The magnitude of the effects of rhIGF-I correlated with the respective control levels.

Since rhIGF-I appears to improve insulin sensitivity directly and/or indirectly, it may become an interesting tool in type 2 diabetes and other states associated with insulin resistance. (J. Clin. Invest. 1992. 90:2234-2241.) Key words: insulin sensitivity • insulin resistance • insulin-like growth factors • noninsulin-dependent diabetes mellitus • proinsulin

\section{Introduction}

Noninsulin-dependent (type 2) diabetes mellitus is characterized by hyperglycemia, hyperinsulinemia, and relatively in-

This work has been presented in part at the 73rd Annual Meeting of the Endocrine Society, Washington, DC, 19-22 June 1991, and at the 27th Annual Meeting of the European Association for the Study of Diabetes, Dublin, Ireland, 11-14 September 1991.

Address correspondence to Dr. Peter D. Zenobi, Division of Endocrinology and Metabolism, Department of Internal Medicine, University Hospital, 8091 Zurich, Switzerland.

Received for publication 10 March 1992 and in revised form 15 June 1992.

J. Clin. Invest.

(c) The American Society for Clinical Investigation, Inc.

$0021-9738 / 92 / 12 / 2234 / 08 \quad \$ 2.00$

Volume 90, December 1992, 2234-2241 creased proinsulin levels as the result of insulin resistance and $\beta$ cell dysfunction (1-3). Hyperinsulinemia downregulates insulin receptors of insulin target tissues $(1,4-6)$ and lowers insulin receptor affinity $(6)$ and tyrosine kinase activity $(5,6)$ whereas hyperglycemia impairs insulin-mediated glucose disposal and $\beta$ cell function (7). Hyperinsulinemia was claimed to be an independent cardiovascular risk factor in many $(8,9)$ but not in all studies (10). Moreover, hyperinsulinemia is often associated with other cardiovascular risk factors such as dyslipoproteinemia (9) and enhanced plasminogen activator inhibitor activity leading to a decreased rate of fibrinolysis (11).

Therapy of type 2 diabetes aims at a loss of body weight by which hyperglycemia, hyperinsulinemia, insulin sensitivity, and glucose tolerance are improved and lipid levels decreased $(12,13)$. However, compliance with reducing diets is often poor and the beneficial effects short lived so that sulfonylureas or insulin are prescribed. Both enhance hyperinsulinemia (14) and can aggravate insulin resistance directly $(5,15)$ or indirectly by increasing body weight $(16,17)$. Therefore, the atherogenic risk rises again $(8,9)$.

Insulin-like growth factor-I (IGF-I) ${ }^{\prime}$ may interrupt this vicious cycle. IGF-I is a growth-promoting and cell differentiation-enhancing factor which mimics many effects of insulin $(18,19)$ via the type 1 IGF and/or the insulin receptor $(6,18$, 19). An intravenous bolus of recombinant human insulin-like growth factor-I (rhIGF-I) caused hypoglycemia in animals and humans $(20,21)$, although with a 12 -fold lower potency on a molar basis than insulin (20). In severe insulin-resistant diabetics who are unresponsive to intravenous insulin, rhIGF-I decreased blood glucose levels into the normoglycemic range (22). RhIGF-I stimulated glucose uptake during a euglycemic clamp in fasted rats to the same maximum as insulin $(23,24)$ but was more effective than insulin in diabetic rats $(24,25)$. Finally, rhIGF-I infusions decreased insulin, C-peptide, and triglyceride levels in healthy subjects without lowering fasting and postprandial glucose levels $(26,27)$. Thus, insulin secretion was partly uncoupled from glucose levels by the infusion of rhIGF-I. Ready explanations for this phenomenon are the suppression of insulin secretion by rhIGF-I (28), the increase of glucose disposal by rhIGF-I $(23,24)$, and probably an improvement of insulin sensitivity via decreased insulin, triglyceride, and growth hormone (GH) levels $(26,27,29)$.

Thus, rhIGF-I appears to improve insulin sensitivity in healthy subjects and to be particularly effective in insulin-resistant diabetics. In this study, we investigated the effects of rhIGF-I on fasting and postprandial glucose, insulin, C-peptide, proinsulin, glucagon, and triglyceride levels in patients

1. Abbreviations used in this paper: AUC, area under the curve; GH, growth hormone; $\mathrm{HBA}_{\mathrm{lc}}$, glycosylated hemoglobin; iAUC, incremental AUC; IGF, insulin-like growth factor; IGFBP, IGF-binding protein; MTT, meal tolerance test; rhIGF-I, recombinant human IGF-I. 
with type 2 diabetes mellitus. We found that rhIGF-I decreased fasting plasma glucose and triglyceride levels and improved meal tolerance in the face of markedly lowered fasting and postprandial insulin and C-peptide levels.

\section{Methods}

Subjects. Eight patients with type 2 diabetes mellitus gave informed and written consent and participated in this study. Their clinical characteristics are given in Table I. 1-2 wk before the study a physical investigation, electrocardiogram stress test, and hematology and chemistry parameters, including a glycosylated hemoglobin $\left(\mathrm{HbA}_{\mathrm{lc}}\right)$ measurement, confirmed that the type 2 diabetic subjects had no severe diabetic complications and were otherwise healthy. Subjects 3 and 8 were treated for hypertension with angiotensin-converting enzyme inhibitors. All female patients were postmenopausal. The weight of the patients remained constant during $4 \mathrm{wk}$ before the study. The patient's usual treatment for type 2 diabetes consisted of diet alone or diet plus Glibenclamide (Table I) but none of them received insulin. A dietary history of each patient served to calculate the diet that the patients received during the study (see below). The protocol was approved by the Ethics committee of the Department of Internal Medicine of the University Hospital at Zurich.

Experimental protocol. Those patients taking Glibenclamide discontinued the drug $3 \mathrm{~d}$ before the study. Throughout the study the patients received a sucrose-free diet of $30 \mathrm{kcal} / \mathrm{kg}$ body weight $(50 \%$ carbohydrates, $30 \%$ fat, and $20 \%$ protein), which was given as breakfast at $8 \mathrm{am}(25 \%$ of the total calories), snack at $10 \mathrm{am}(10 \%)$, lunch at 12 am (25\%), snack at $4 \mathrm{pm}(10 \%)$, dinner at $6: 30 \mathrm{pm}(25 \%)$, and the bedtime snack at 9:30 pm (5\%). The composition of the breakfast was identical for each patient throughout the study.

The study lasted $12.5 \mathrm{~d}$ and was started with a control period (days $1-5$ ), followed by the rhIGF-I treatment period (days 6-10), and concluded with the wash-out period of $2.5 \mathrm{~d}$ (days 11-13). The patients were hospitalized throughout except for days $1-3$, on which they came to the hospital for the main meals. Since rhIGF-I affects serum levels of many parameters for several days after its discontinuation, the control and treatment period could not be randomized. Instead, we followed the patients during the wash-out days. In a recent study (26), healthy subjects received intravenous infusions of 7 and $14 \mu \mathrm{g} \mathrm{rhIGF-I/kg} \mathrm{per} \mathrm{h}$ (equal to 84 and $168 \mu \mathrm{g} / \mathrm{kg}$ two times per day). The higher dose was barely more effective than the lower one. A dose response in a Laron dwarf (30) showed that $16 \mu \mathrm{g}$ rhIGF-I/kg per h caused fasting hypoglycemia and postprandial hyperglycemia. Therefore, we chose a dose in this study which was between those used in healthy subjects. RhIGF-I, kindly provided by Ciba-Geigy AG (Basel, Switzerland), was dissolved in $0.9 \%$ saline $(10 \mathrm{mg} / \mathrm{ml})$ and on days $6-10,120 \mu \mathrm{g} \mathrm{rhIGF-I/kg} \mathrm{body}$ weight was subcutaneously injected into the thigh two times per day ( 7 am and 6:30 pm), except for day 10 when the injection at $6: 30 \mathrm{pm}$ was omitted.

After $10 \mathrm{~h}$ of fasting, blood was drawn at 7:30 am on days $1,4,5$, and $8-13$, and at 7 am on days 6 and 7 for the analysis of glucose, insulin, C-peptide, proinsulin, glucagon, total triglyceride, total IGF-I and IGF-II, free IGF-I, and GH levels. Fasting plasma glucose was also determined at 7 am during the treatment period and at 7 am on days 11 and 12 in patients 5-8. Additional plasma glucose levels were determined daily before each main meal, at $9: 30 \mathrm{pm}$ on days 4-10 in all patients and at 9:30 pm on days 11 and 12 in patients 2 and 5-8.

A meal tolerance test (MTT) was performed on days 4, 5, and 8-12. On these days the snack at 10 am was omitted and was eaten with the breakfast between 8 and 8:30 am, containing $87 \pm 11 \mathrm{~g}$ carbohydrates $(1.2 \mathrm{~g} / \mathrm{kg})$. At least $30 \mathrm{~min}$ before the start of the MTT, an 18-gauge Venflon (Braun Melsungen AG, Melsungen, FRG) cannula was inserted into a forearm vein to draw blood for the determination of the above-mentioned parameters. GH was determined at 10 and 12 am during MTT.

Methods. Blood was drawn into tubes containing sodium fluoride and oxalate, centrifuged within $10 \mathrm{~min}$, and immediately analyzed for plasma glucose on a glucose analyzer (Glucose Analyzer 2; Beckman Instruments, Inc., Fullerton, CA). Venous blood was drawn into SST tubes (Becton Dickinson, Meylan Cedex, France). After clot retraction during $30 \mathrm{~min}$ at $4^{\circ} \mathrm{C}$ and centrifugation at $1,550 \mathrm{~g}$ for $30 \mathrm{~min}$ at $4^{\circ} \mathrm{C}$, aliquots of serum were stored at $-20^{\circ} \mathrm{C}$ until assayed. Insulin, C-peptide, and GH were determined using commercial RIAs (Medipro AG, Teufen, Switzerland). Triglycerides were hydrolyzed and glycerol was determined by an enzymatic, photometrical determination (Boehringer Mannheim AG, Mannheim, FRG) on a Hitachi 717 (Boehringer, Mannheim, AG). ELISA for proinsulin (31) and RIAs for the determination of glucagon, total IGF-I, total IGF-II, and free IGF-I levels, respectively, were performed as described $(26,32)$. All samples of one patient were analyzed in duplicate at one to three dilutions within one or two assays. The interassay coefficients of variation were 7.5 and $6.3 \%$ for insulin ( 180 and $680 \mathrm{pmol} /$ liter), 5.1 and $4.1 \%$ for C-peptide (360 and 1,110 pmol/liter), $9.0 \%$ for proinsulin (between 18 and $28 \mathrm{pmol} / \mathrm{liter}), 13.8 \%$ for $\mathrm{GH}(320 \mathrm{ng} / \mathrm{ml}), 13.5 \%$ for total IGF-I (between 13 and $27 \mathrm{nmol} /$ liter), $14.0 \%$ for total IGF-II ( $81 \mathrm{nmol} /$ liter), and $12.6 \%$ for free IGF-I ( 2.8 and $12.8 \mathrm{nmol} /$ liter), respectively. $\mathrm{HbA}_{\mathrm{lc}}$ was determined with a semiautomated cation-exchange column chromatography system (MDMF; Bio-Rad Laboratories, Richmond, CA).

Statistics. All data are presented as mean \pm SD. The results of this study, comprising eight subjects, cannot be expected to be normally distributed. Therefore, paired differences were analyzed using the twotailed Wilcoxon's matched pairs signed-rank test. Areas under the curve (AUC) and linear regressions were calculated using the trapezoi-

Table I. Clinical Characteristics of the Patients with Type 2 Diabetes Mellitus

\begin{tabular}{|c|c|c|c|c|c|c|}
\hline Patient & Sex & Age & BMI & Diabetes & $\mathrm{HbA}_{\mathrm{Ic}}{ }^{*}$ & $\begin{array}{l}\text { Previous } \\
\text { therapy }\end{array}$ \\
\hline & & $y r$ & $\mathrm{~kg} / \mathrm{m}^{2}$ & $y r$ & $\%$ & \\
\hline 1 & $\mathbf{M}$ & 50.5 & 24 & 8 & 6.9 & Diet, Gc \\
\hline 2 & $\mathbf{M}$ & 46 & 24 & 4 & 10.5 & Diet, Gc \\
\hline 3 & $\mathbf{M}$ & 48.5 & 28 & 2 & 6.6 & Diet \\
\hline 4 & $\mathbf{M}$ & 41.5 & 26 & 0.5 & 5.8 & Diet, Gc \\
\hline 5 & $\mathrm{~F}$ & 57 & 23 & 10 & 6.8 & Diet, Gc \\
\hline 6 & $\mathbf{M}$ & 40.5 & 33 & 5 & 6.4 & Diet \\
\hline 7 & $\mathbf{M}$ & 38 & 27 & 10 & 10.3 & Diet, Gc \\
\hline 8 & $\mathrm{~F}$ & 60 & 24 & 14 & 11.0 & Diet, Gc \\
\hline Mean \pm SD & & $48 \pm 8$ & $26 \pm 3$ & $7 \pm 5$ & $8.0 \pm 2.2$ & \\
\hline
\end{tabular}

BMI, body mass index; F, female; Gc, Glibenclamide; $M$, male.

* Normal range: $4.0-6.4 \%$. 
Table II. Fasting Total IGF-I, Free IGF-I, and Total IGF-II Levels*

\begin{tabular}{rccc}
\hline Day & Total IGF-I & Free IGF-I & Total IGF-II \\
\hline & & $n$ mol/liter & \\
1 & $21.2 \pm 7.4$ & $2.3 \pm 1.1$ & $99 \pm 13$ \\
4 & $20.7 \pm 6.4$ & $2.3 \pm 1.2$ & $93 \pm 15$ \\
5 & $21.3 \pm 6.6$ & $2.9 \pm 2.2$ & $96 \pm 17$ \\
6 & $23.5 \pm 7.2$ & $2.5 \pm 1.3$ & $100 \pm 26$ \\
7 & $98.5 \pm 16.3^{\ddagger}$ & $3.9 \pm 1.3$ & $49 \pm 22^{\ddagger}$ \\
8 & $124.1 \pm 23.0^{\ddagger}$ & $7.3 \pm 2.6^{* \ddagger}$ & $31 \pm 12^{\ddagger}$ \\
9 & $105.6 \pm 16.7^{\ddagger}$ & $6.4 \pm 1.7^{* \ddagger}$ & $28 \pm 13^{\ddagger}$ \\
10 & $106.4 \pm 21.2^{\ddagger}$ & $5.2 \pm 1.6^{\S}$ & $22 \pm 8^{\ddagger}$ \\
11 & $55.2 \pm 14.3^{\ddagger \prime \prime}$ & $2.4 \pm 1.5^{\prime \prime}$ & $37 \pm 11^{\ddagger}$ \\
12 & $33.4 \pm 9.5^{\ddagger \prime}$ & $2.5 \pm 1.5^{\prime \prime}$ & $55 \pm 12^{* \ddagger 1}$ \\
13 & $24.0 \pm 5.2^{\S}$ & $2.5 \pm 1.2^{\ddagger}$ & $71 \pm 14^{\ddagger 1}$ \\
& & & \\
\hline
\end{tabular}

* Mean \pm SD of the fasting total IGF-I, free IGF-I, and total IGF-II levels before (days 1-5), during (days 6-10), and after (days 11-13) treatment subcutaneously with $2 \times 120 \mu \mathrm{g}$ rhIGF-I/kg daily. ${ }^{\ddagger} P$ $<0.01,{ }^{8} P<0.05$ vs mean of days $1-5$; ${ }^{11} P<0.01,{ }^{7} P<0.02$ vs. mean of days $7-10$.

dal rule and the method of least squares, respectively. A $P$ value of $<0.05$ was considered significant.

\section{Results}

All patients tolerated the rhIGF-I treatment well. Body weight and resting and postural blood pressure did not change during the study. An asymptomatic but significant increase of the heart rate by 9 to $17 \%$ was noted between days 7 and 12 . On day 7, mild tenderness in the area of the parotid gland was reported by all patients. It lasted 3-6 d and was accompanied by a slight swelling of the parotid gland for 3 to $4 \mathrm{~d}$, which was also noticed by four of eight patients.

IGF levels (Table II) remained constant and in the normal range during the control period. Total and free IGF-I levels were significantly increased $24 \mathrm{~h}$ after starting rhIGF-I administration, and total IGF-II levels were decreased. On days 8-10, total and free IGF-I levels were 5.3 and 2.5 times above control levels, respectively, whereas total IGF-II levels were decreased to $28 \%$. Free IGF-I levels reached control levels again on day 11 , whereas total IGF-I and -II levels were still slightly different from control levels on day 13. During rhIGF-I administration total IGF levels did not markedly change throughout the day, including MTT, whereas free IGF-I levels peaked at 9 am during MTT (Table III). GH levels were clearly decreased by rhIGF-I treatment (Table IV).

Fasting (Fig. 1) and preprandial plasma glucose levels (11.9 \pm 5.6 before lunch and $11.7 \pm 5.0 \mathrm{mmol} /$ liter before dinner, respectively) remained constant during the control days, decreased $24 \mathrm{~h}$ after starting treatment, reached the nadir (6.6 \pm 2.5 fasting, $7.7 \pm 3.0$ before lunch, and $8.7 \pm 2.2 \mathrm{mmol} / \mathrm{liter}$ before dinner, respectively) on day 10 , and did not markedly increase on days 11 and 12 . Fructosamine levels decreased markedly from day $6(398 \pm 200 \mu \mathrm{mol} /$ liter $)$ to day $10(319 \pm 123$ $\mu \mathrm{mol} /$ liter; $P<0.01$ ). The difference of the fasting plasma glucose levels between the control and the treatment period correlated with the fasting glucose values during the control period

Table III. Total IGF-I, Free IGF-I, and Total IGF-II Levels during MTT*

\begin{tabular}{|c|c|c|c|c|}
\hline Time & $\begin{array}{c}\text { Days } 4 \\
\text { and } 5\end{array}$ & Day 8-10 & Day 11 & Day 12 \\
\hline \multicolumn{5}{|c|}{ Total IGF-I (nmol/liter) } \\
\hline 08:00 & $21 \pm 5$ & $116 \pm 21^{\ddagger}$ & $52 \pm 14^{\ddagger \S}$ & $31 \pm 9^{\neq \S \|}$ \\
\hline 08:30 & $21 \pm 6$ & $130 \pm 23$ & $57 \pm 14$ & $33 \pm 8$ \\
\hline 09:00 & $21 \pm 5$ & $127 \pm 22^{\prime}$ & $50 \pm 11$ & $35 \pm 12$ \\
\hline $10: 00$ & $19 \pm 6$ & $122 \pm 18^{* * \ddagger \ddagger}$ & $48 \pm 11^{1 * *}$ & $30 \pm 6^{* * \# \pm}$ \\
\hline $11: 00$ & $20 \pm 5^{1}$ & $120 \pm 19^{* *}$ & $47 \pm 12^{* *}$ & $29 \pm 6^{* * \neq \ddagger}$ \\
\hline $12: 00$ & $20 \pm 5^{* * \neq}$ & $117 \pm 20^{* * \pm \ddagger}$ & $48 \pm 10^{* *}$ & $30 \pm 5$ \\
\hline \multicolumn{5}{|c|}{ Free IGF-I (nmol/liter) } \\
\hline 08:00 & $2.5 \pm 1.1$ & $7.7 \pm 1.5^{\ddagger}$ & $2.6 \pm 1.3^{\S}$ & $2.7 \pm 2.1^{\S}$ \\
\hline 08:30 & $2.5 \pm 1.3$ & $9.2 \pm 2.7$ & $3.0 \pm 1.0$ & $2.4 \pm 1.8$ \\
\hline 09:00 & $2.3 \pm 1.0$ & $9.8 \pm 1.7^{4}$ & $2.8 \pm 2.0$ & $2.5 \pm 2.3$ \\
\hline $10: 00$ & $2.2 \pm 1.0$ & $8.9 \pm 1.9$ & $2.8 \pm 1.5$ & $2.8 \pm 2.0^{* *}$ \\
\hline $11: 00$ & $2.6 \pm 1.3$ & $8.3 \pm 1.7$ & $3.0 \pm 1.5$ & $2.1 \pm 0.8$ \\
\hline $12: 00$ & $2.7 \pm 1.2$ & $7.3 \pm 1.1^{\ddagger \ddagger}$ & $3.1 \pm 1.6$ & $2.4 \pm 1.1$ \\
\hline \multicolumn{5}{|c|}{ Total IGF-I (nmol/liter) } \\
\hline 08:00 & $93 \pm 18$ & $27 \pm 11^{\ddagger}$ & $37 \pm 8^{\ddagger}$ & $57 \pm 16^{6 \$ 11}$ \\
\hline 08:30 & $96 \pm 17$ & $28 \pm 13^{\prime}$ & $43 \pm 12^{\prime \prime}$ & $62 \pm 15$ \\
\hline 09:00 & $92 \pm 19$ & $27 \pm 12^{* *}$ & $38 \pm 9$ & $60 \pm 14$ \\
\hline $10: 00$ & $88 \pm 12$ & $26 \pm 11^{* * * \ddagger}$ & $39 \pm 12$ & $60 \pm 12$ \\
\hline $11: 00$ & $92 \pm 15$ & $25 \pm 9^{1 * *}$ & $41 \pm 15$ & $61 \pm 15$ \\
\hline $12: 00$ & $90 \pm 18$ & $25 \pm 11^{* * \neq \pm}$ & $45 \pm 10^{1 \neq \pm}$ & $61 \pm 15$ \\
\hline
\end{tabular}

\footnotetext{
* Mean \pm SD of total IGF-I, free IGF-I, and total IGF-II levels before ( $8 \mathrm{am}$ ) and during MTT, before (days 4 and 5), during (days 8-10), and after (days 11 and 12) treatment subuctaneously with $2 \times 120 \mu \mathrm{g}$ rhIGF-I/kg daily. $P<0.01$ for each time point of the day(s) vs. the respective time points during days 4 and 5 , ${ }^{\S}$ days $8-10$, and 1 day 11 , respectively. ${ }^{1} P<0.05$ vs. 8:00, ${ }^{* *} P<0.05$ vs. 8:30, and ${ }^{\ddagger \neq} P<0.05$ vs. $9: 00$ of the same day, respectively.
} 
Table IV. GH Levels before, during, and after rhIGF-I Treatment

\begin{tabular}{|c|c|c|c|c|}
\hline Time & $\begin{array}{c}3 \mathrm{am} \\
(n=4)\end{array}$ & $\begin{array}{c}7: 30 \mathrm{am} \\
(n=8)\end{array}$ & $\begin{array}{c}10 \mathrm{am} \\
(n=8)\end{array}$ & $\begin{array}{c}12 \mathrm{am} \\
(n=8)\end{array}$ \\
\hline & \multicolumn{4}{|c|}{$n g / m l$} \\
\hline Control period & $0.24 \pm 0.08$ & $0.49 \pm 0.37$ & $0.22 \pm 0.05$ & $0.70 \pm 1.0$ \\
\hline Treatment period & $<0.20$ & $0.22 \pm 0.05$ & $<0.20$ & $0.23 \pm 0.08$ \\
\hline Washout period & $0.22 \pm 0.03$ & $0.20 \pm 0.04$ & $<0.20$ & $0.82 \pm 1.0$ \\
\hline
\end{tabular}

Mean \pm SD of GH levels at different time points during the day before (control period), during (treatment period), and after (wash-out period) treatment subcutaneously with $2 \times 120 \mu \mathrm{g}$ hIGF-I/ $\mathrm{kg}$ daily.

(Fig. 2) and the $\mathrm{HbA}_{1 \mathrm{c}}$ levels of the screening visit $(r=0.844, P$ $<0.01)$. Thus, the absolute decrease of glucose levels was smaller in patients 1 and 3-6, who started with relatively low glucose levels during the control period $(7.6 \pm 2.8 \mathrm{mmol} / \mathrm{liter})$. These patients reached normal fasting plasma glucose levels on days 9 and 10 (5.2 $\pm 1.1 \mathrm{mmol} / \mathrm{liter})$.

Fasting insulin and C-peptide levels reached the nadir on days 10 and 9 , respectively, increased again on day 11 , and reached control values on day 13 (Fig. 1). Fasting triglyceride
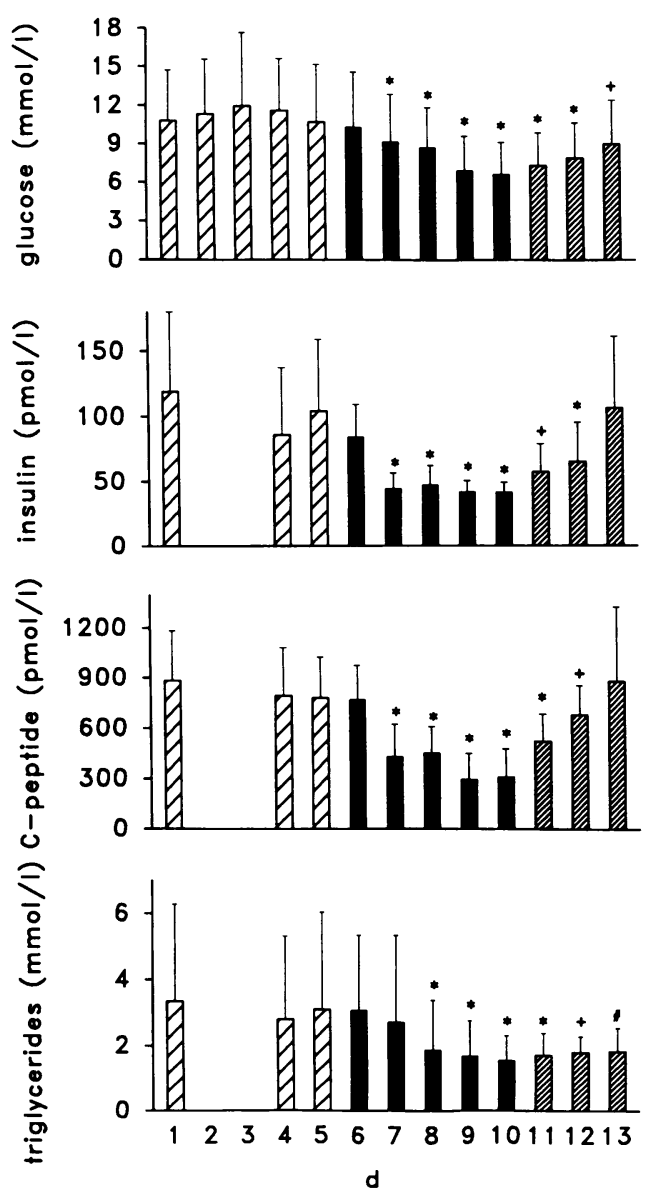

Figure 1. Effects of rhIGF-I on fasting glucose, insulin, C-peptide, and triglyceride levels. Mean + SD of plasma glucose (top panel), insulin (upper middle panel), C-peptide (lower middle panel), and total triglyceride levels (bottom panel) in eight type 2 diabetics before (coarsely hatched bars), during (solid bars), and after (hatched bars) treatment subcutaneously with $2 \times 120 \mu \mathrm{g}$ rhIGF-I/kg daily. ${ }^{*} P$ $<0.01,{ }^{+} P<0.02,{ }^{*} P<0.05$ vs. control. levels fell to a minimum on day 10 and remained decreased until day 13 (Fig. 1). The decrease of fasting insulin, C-peptide, and triglyceride levels during rhIGF-I treatment correlated with the respective fasting control levels (Fig. 2). In the case of
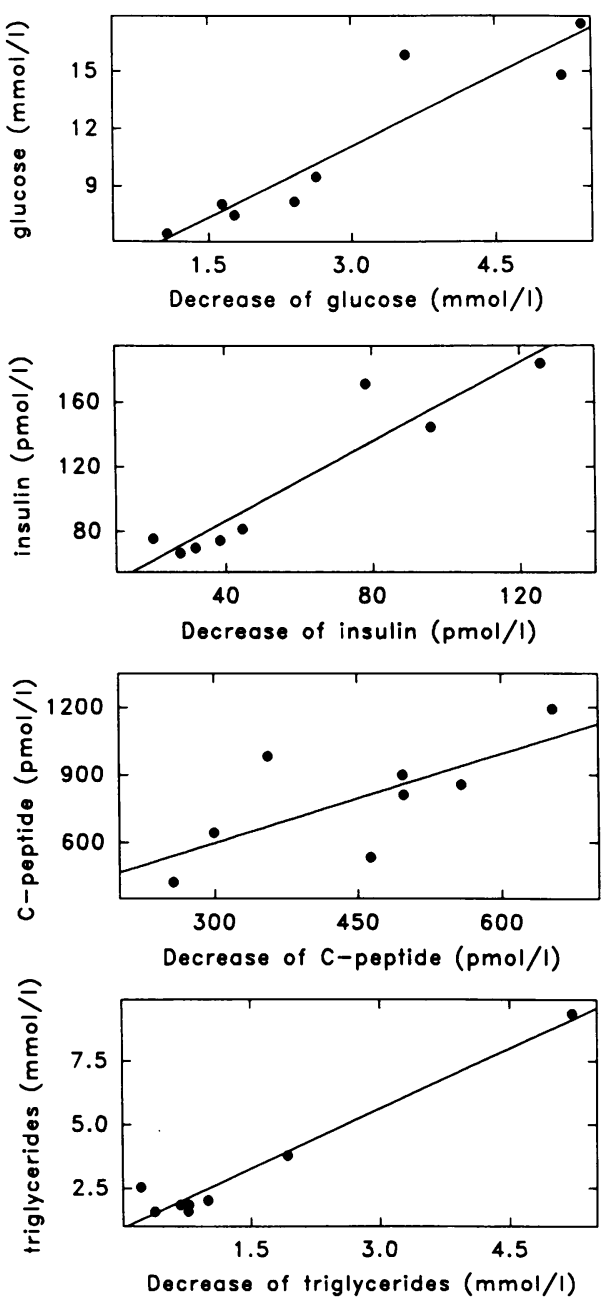

Figure 2. Decrease of fasting glucose, insulin, C-peptide, and triglyceride levels during rhIGF-I treatment compared with the control levels. The differences between the mean fasting plasma glucose, insulin, C-peptide, and total triglyceride levels during the control and the treatment period are correlated with the fasting plasma glucose (top panel: $y=2.49 x+3.64, r=0.932, P<0.001$ ), insulin (upper middle panel: $y=1.23 x+38, r=0.938, P<0.001$ ), C-peptide (lower middle panel: $y=1.32 x+202, r=0.711, P<0.05)$, and total triglyceride levels (bottom panel: $y=1.57 x+0.92, r=0.976, P<0.001$ ) during the control period. Each circle represents the value of one subject. 

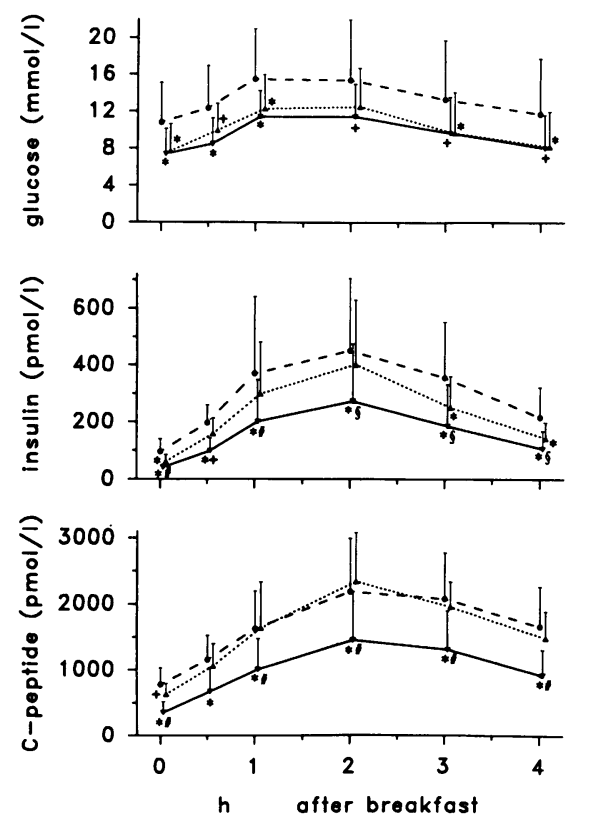

Figure 3. Effects of rhIGF-I on postprandial glucose, insulin, and C-peptide levels. Plasma glucose (top panel), insulin (middle panel), and C-peptide levels (bottom panel) in eight type 2 diabetics before $(0 \mathrm{~h})$ and during a MTT (standard breakfast). The values represent the mean + SD of the two MTTs on days 4 and 5 during the control period (coarsely hatched line, circles), three MTTs on days 8-10 during treatment subcutaneously with $2 \times 120 \mu \mathrm{g}$ rhIGF-I/kg daily (solid line, downward triangles), and two MTTs on days 11 and 12 during the wash-out period (dotted line, upward triangles). ${ }^{*} P<0.01,{ }^{+} P$ $<0.05$ vs. control, ${ }^{*} P<0.01,{ }^{\S} P<0.05$ vs. wash-out.

triglycerides, the correlation remained almost significant ( $r$ $=0.73, P=0.56)$ even if the data pair of the patient with clearly increased fasting triglyceride levels was excluded from statistical analysis.

During rhIGF-I administration, postprandial glucose, insulin, and C-peptide levels were markedly decreased but only glucose levels remained decreased during the wash-out period (Fig. 3). The decrease of both total AUC and incremental AUC (iAUC) for glucose, insulin, and C-peptide during rhIGF-I treatment (Table V) cannot solely be explained by the decreased fasting levels. The diminution of the $\mathrm{AUC}_{\text {glucose }}$ during rhIGF-I treatment was related to the fasting plasma glucose levels $(r=0.846, P<0.01)$ and to the $\mathrm{AUC}_{\text {glucose }}$ during the
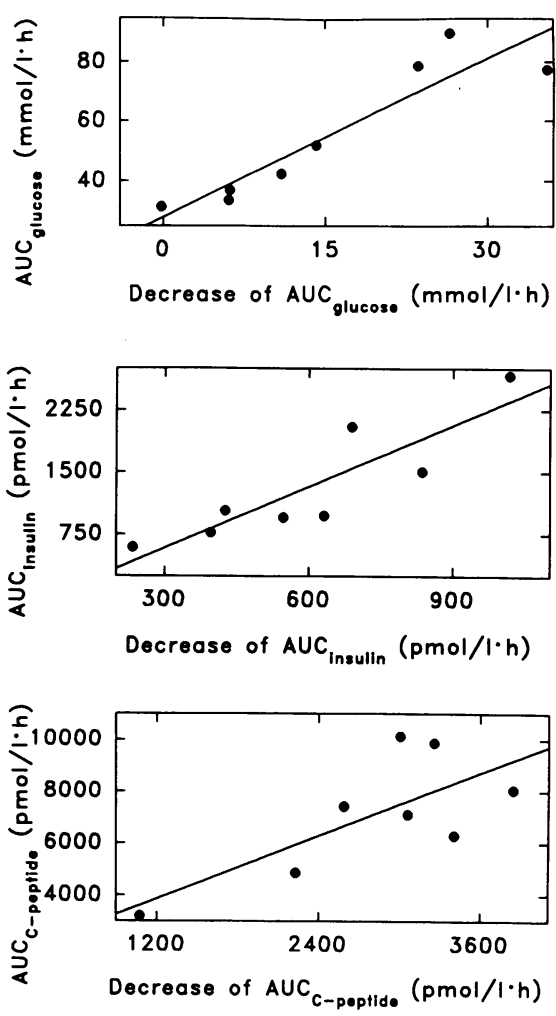

Figure 4. Decrease of the postprandial area under the glucose, insulin, and C-peptide curve during rhIGF-I treatment versus the respective area during the control period. The areas under the glucose $\left(A U C_{\text {glucose }}\right)$, insulin $\left(A U C_{\text {insulin }}\right)$, and C-peptide $\left(A U C_{C \text {-peptide }}\right)$ curve during MTT and the differences between these AUCs during the control and the treatment period were calculated. The AUCs during the control period are plotted versus the decrease of the $\mathrm{AUC}_{\text {glucose }}$ (top panel: $y=1.78 x+27.8, r=0.924, P<0.001$ ), $\mathrm{AUC}_{\mathrm{insulin}}$ (middle panel: $y=2.48 x-157, r=0.879, P<0.01)$, and $\mathrm{AUC}_{\text {C-peptide }}$ (bottom panel: $y=2.03 x+1429, r=0.735, P<0.05$ ) during rhIGF-I treatment. Each circle represents the value of one subject.

control period (Fig. 4). The differences of the $\mathrm{AUC}_{\text {insulin }}$ and of the $\mathrm{AUC}_{\mathrm{C} \text {-peptide }}$ between the control and the treatment period correlated with the respective AUC during the control period (Fig. 4).

Fasting and postprandial proinsulin levels and the proinsulin/insulin ratio were clearly decreased during rhIGF-I administration as well as on day 12 (Table VI).

Table V. Total and Incremental Area Under the Glucose, Insulin, and C-peptide Curve during the MTT before, during, and after rhIGF-I Treatment

\begin{tabular}{|c|c|c|c|c|}
\hline & Days 4 and 5 & Days 8-10 & Day 11 & Day 12 \\
\hline $\operatorname{AUC}_{\text {glucose }}($ mmol/liter per $h)$ & $55 \pm 23$ & $40 \pm 13^{8}$ & $41 \pm 14^{\ddagger}$ & $44 \pm 17^{\ddagger * *}$ \\
\hline $\mathrm{iAUC}_{\text {glucose }}(\mathrm{mmol} / \mathrm{liter}$ per $\mathrm{h})$ & $15 \pm 5$ & $11 \pm 2^{\S}$ & $13 \pm 4$ & $14 \pm 4$ \\
\hline $\mathrm{AUC}_{\text {insulin }}(p m o l / l i t e r$ per $h)$ & $1,322 \pm 712$ & $725 \pm 504^{\ddagger}$ & $1,069 \pm 598$ & $1,122 \pm 604^{\prime \prime}$ \\
\hline $\mathrm{iAUC}_{\text {insulin }}(p m o l / l i t e r$ per $h)$ & $921 \pm 511$ & $547 \pm 481^{\ddagger}$ & $805 \pm 478^{\prime}$ & $855 \pm 520$ \\
\hline $\mathrm{AUC}_{\mathrm{C} \text {-peptide }}(\mathrm{pmol} / \mathrm{liter} \mathrm{per} h)$ & $7,117 \pm 2,353$ & $4,309 \pm 1,819^{\ddagger}$ & $6,468 \pm 1,645^{1}$ & $7,137 \pm 1,993^{\prime}$ \\
\hline $\mathrm{iAUC}_{\mathrm{C}-\text { peptide }}(\mathrm{pmol} /$ liter per $h)$ & $4,045 \pm 1,563$ & $2,994 \pm 1,459^{\ddagger}$ & $4,498 \pm 1,373^{\prime}$ & $4,436 \pm 1,575^{* *}$ \\
\hline
\end{tabular}

AUC and iAUC for glucose, insulin, and C-peptide during the MTT before (days 4 and 5), during (days 8-10), and after (days 11 and 12) treatment subcutaneously $2 \times 120 \mu \mathrm{g}$ rhIGF-I/kg daily. ${ }^{\ddagger} P<0.01,{ }^{8} P<0.02, " 11 P<0.05$ vs. days 4 and $5 ;{ }^{7} P<0.01,{ }^{* *} P<0.05$ vs. days $8-10$. 
Table VI. Proinsulin Levels and Proinsulin/Insulin Ratio before, during, and after rhIGF-I Treatment

\begin{tabular}{|c|c|c|c|c|}
\hline & \multicolumn{2}{|c|}{ Proinsulin } & \multicolumn{2}{|c|}{ Proinsulin/insulin ratio } \\
\hline & $7: 30 \mathrm{am}$ & $10: 00 \mathrm{am}$ & $7: 30 \mathrm{am}$ & 10:00 am \\
\hline \multicolumn{5}{|c|}{ pmol/liter } \\
\hline Day 4 & $24 \pm 13$ & $67 \pm 33$ & $0.75 \pm 1.12$ & $0.22 \pm 0.17$ \\
\hline Day 5 & $23 \pm 13$ & $67 \pm 28$ & $0.38 \pm 0.36$ & $0.21 \pm 0.12$ \\
\hline Day 9 & $8 \pm 5^{\ddagger}$ & $28 \pm 15^{\ddagger}$ & $0.26 \pm 0.30^{\S}$ & $0.16 \pm 0.11^{\S}$ \\
\hline Day 10 & $7 \pm 5^{\ddagger}$ & $30 \pm 20^{\ddagger}$ & $0.19 \pm 0.18^{\ddagger}$ & $0.15 \pm 0.11^{11}$ \\
\hline Day 12 & $12 \pm 5^{\ddagger}$ & $54 \pm 33$ & $0.37 \pm 0.41^{\S}$ & $0.21 \pm 0.23$ \\
\hline
\end{tabular}

Mean \pm SD of fasting (7:30 am) and postprandial (10:00 am) proinsulin levels and the proinsulin/insulin ratio before (days 4 and 5), during (days 9-10), and after (day 12) treatment subcutaneously with $2 \times 120 \mu \mathrm{g} \mathrm{rhIGF}-\mathrm{I} / \mathrm{kg}$ daily. ${ }^{\ddagger} P<0.01,{ }^{8} P<0.02,{ }^{\|} P<0.05$ vs. days 4 and 5 .

Fasting glucagon levels did not change during rhIGF-I administration (not shown).

The insulin/glucose ratio can be considered as an index of tissue sensitivity to insulin (33). The fasting insulin/glucose ratio (mean $\pm \mathrm{SD}$ ) during the control period was $11.7 \pm 9.2 \times 10^{6}$ and decreased to $6.3 \pm 2.6 \times 10^{6}$ during the treatment period $(P$ $<0.01)$. The ratio decreased similarly in the postprandial state during rhIGF-I administration (not shown). The fasting and postprandial C-peptide/insulin ratio was not changed by rhIGF-I administration as can be deduced from the data in Figs. 1 and 3.

\section{Discussion}

RhIGF-I exerts insulin-like effects in isolated cells and organs, and in the intact organism (18-21). Free IGF-I levels are markedly increased after an intravenous bolus of rhIGF-I whereby glucose disposal via type 1 IGF and insulin receptors is stimulated $(6,18)$, causing hypoglycemia in animals and humans $(20,21)$. In diabetics with severe insulin resistance, normoglycemia after an intravenous rhIGF-I bolus results mostly from the interaction of free IGF-I with type 1 IGF receptors (22). During a euglycemic clamp in fasted rats, rhIGF-I and insulin increased glucose uptake similarly (23), but rhIGF-I was clearly more effective than insulin in diabetic rats $(24,25)$. In the present study, rhIGF-I administration lowered fasting plasma glucose levels and improved meal tolerance despite markedly decreased insulin and C-peptide levels (Figs. 1 and 3).

Elevated IGF-I levels are not always associated with insulin-like effects. In acromegaly, GH excess increases total IGF-I levels into the same range as rhIGF-I administration did in this study (34) but GH excess causes insulin resistance and impaired glucose tolerance in the presence of elevated insulin levels (35). On the other hand, suppressed GH levels after treatment of acromegaly (35) or during rhIGF-I administration (Table IV and reference 26) lower insulin levels and improve glucose tolerance $(26,35)$.

Furthermore, serum IGF-binding proteins (IGFBPs), which are important regulators of IGF action, undergo different changes during $\mathrm{GH}$ excess and rhIGF-I administration, respectively. In this and previous studies rhIGF-I administration elevated free IGF-I serum levels (Tables II and III, and refer- ence 26 ) and increased IGFBP-1 and -2 serum levels (36) by way of decreased insulin levels $(37,38)$. Thus, serum levels of free IGF-I are increased during rhIGF-I infusions, and IGFBP1 and -2 , which have a short half-life, carry relatively large amounts of the total serum IGF-I (39). Free IGF-I and IGF-I bound to IGFBP-1 were shown to cross the vascular barrier of the rat heart (40) so that during rhIGF-I administration a large portion of IGF-I may stimulate glucose disposal in muscle via type 1 IGF and/or insulin receptors $(6,18,19)$. This increase of free IGF-I and the changed IGF-I distribution among IGFBPs could counterbalance the diminished insulin levels with respect to glucose disposal (Figs. 1 and 3). In contrast, increased GH levels in acromegaly induce IGFBP-3 and the acid-labile subunit of the IGFBP-3 complex $(34,36,41)$ with a high IGFbinding capacity (41). The concomitantly increased insulin levels (35) suppress IGFBP-1 and -2 production (42) and lower their serum levels. Hence, IGF-I in acromegaly is mostly bound to the IGFBP-3 complex and, in that form, stimulates anabolic and growth processes (43) rather than glucose metabolism.

Fasting and postprandial insulin and C-peptide levels may also have been lowered indirectly due to the decreased plasma glucose levels during rhIGF-I administration. Furthermore, IGF-I has been shown to directly suppress insulin secretion in the perfused rat pancreas (28). In contrast, our data suggest that IGF-I has no marked effect on glucagon secretion. Improved metabolic control (17) and the partial suppression of insulin secretion may have been responsible for the decreased fasting and postprandial proinsulin levels and proinsulin/insulin ratio (Table VI), suggesting a beneficial effect of rhIGF-I on $\beta$ cell function in type 2 diabetes. On the other hand, suppression of insulin secretion by rhIGF-I may be such that the diminished and delayed postprandial insulin response results in glucose intolerance. This was reported in a child with Laron-type dwarfism in whom an infusion of $16 \mu \mathrm{g}$ rhIGF-I/ $\mathrm{kg}$ per $\mathrm{h}$ caused fasting hypoglycemia and, at the same time, glucose intolerance (30). We observed in a recent study in healthy humans that a dose of $14 \mu \mathrm{g}$ rhIGF-I/ kg per h shifted the glucose peak slightly to the right after a glucose challenge but did not markedly change glucose levels (26). The small rhIGF-I dose in this study was not diabetogenic in type 2 diabetics but (near-)normalized plasma glucose levels in the face of clearly lowered insulin and C-peptide levels (Figs. 1 and 3).

A moderate decrease of insulin levels during dieting and weight loss improves insulin sensitivity of hyperinsulinemic patients with type 2 diabetes and obesity $(4,12)$. Likewise, nondiabetics with low normal insulin levels are more sensitive to insulin than those with high normal levels (44). Furthermore, insulin sensitivity is also improved by lowering glucose (7) and triglyceride levels (45). In this study, rhIGF-I decreased fasting and postprandial glucose, insulin, and triglyceride levels, i.e., effects each of which could by itself have improved insulin sensitivity. The effect of rhIGF-I was more marked in those diabetics with high starting levels of these metabolic parameters (Figs. 2 and 4). This finding confirms results in healthy humans in whom rhIGF-I lowered insulin levels better, the higher their fasting insulin levels were before treatment (26). It is, however, in sharp contrast with the effects of insulin, which decreases higher glucose levels less effectively than those that are only slightly elevated. Finally, the fasting insulin levels during the control period and on the last wash-out day were comparable. They were accompanied by hyperglycemia during the 
control period and euglycemia on the last wash-out day when free IGF-I levels were back to normal but glucose, insulin, triglyceride, and GH levels still decreased. All these findings support the hypothesis that rhIGF-I may improve insulin sensitivity indirectly.

It would have been preferable to randomize the control and treatment period of this study to avoid a possible bias due to the change of the diet. However, this was impossible because of the long-lasting effects of rhIGF-I after its discontinuation. A major bias in our nonrandomized study design can be excluded for the following reasons: The diet during the study was calculated on the basis of the dietary history of each patient so that no big dietary changes occurred. Patients did not lose weight during the control or treatment period. Blood glucose levels were similar during the first $3 \mathrm{~d}$ on diet, during which the patients came to the hospital only for the main meals, as on day 4 and 5 , during which the patients were hospitalized.

Weight loss is the most reasonable therapeutic approach to most overweight type 2 diabetic patients. It improves insulin sensitivity and glucose tolerance and lowers insulin, glucose, and triglyceride levels $(12,13)$. However, these improvements often do not last very long and sulfonylureas or insulin are added. These agents are well known to lower glucose levels, yet with some risk of hypoglycemia (16). In this study with rhIGF-I treatment, no hypoglycemia occurred although near-normoglycemia was achieved. Furthermore, sulfonylureas and insulin enhance hyperinsulinemia (14), can aggravate insulin resistance directly $(5,15)$ or indirectly by increasing body weight $(16,17)$, and, thereby, increase the atherogenic risk $(8,9)$. Since in this short-term study rhIGF-I lowered not only glucose and triglyceride but also insulin levels, all of which are considered to be cardiovascular risk factors $(8,9)$, rhIGF-I treatment could, in the long run, have beneficial effects on cardiovascular morbidity and mortality.

Thus, rhIGF-I treatment has obvious theoretical advantages compared with conventional therapies of type 2 diabetes mellitus. However, this is a short-term study and we do not know whether the positive effects of rhIGF-I on glucose and lipid metabolism in type 2 diabetics persist during prolonged administration and whether the stimulation of retinal endothelial and smooth muscle cell proliferation by rhIGF-I in vitro $(46,47)$ may have a harmful corollary in vivo. The same holds true for the increased heart rate during rhIGF-I administration (see Results), which remains unexplained and may increase the risk for myocardial ischemia. An association between total IGF-I serum levels and diabetic complications was found in some $(48)$ and not in other studies $(49,50)$. Furthermore, the suppression of GH during rhIGF-I administration may be beneficial for diabetics since $\mathrm{GH}$ has been implicated in the pathogenesis of diabetic complications (51).

The possibility of interrupting the vicious cycle of insulin resistance, hyperinsulinemia, and hyperglycemia by rhIGF-I administration is exciting. However, we obviously need longterm trials and very careful retinal, renal, and cardiovascular monitoring before rhIGF-I can be investigated in a larger group of patients with type 2 diabetes mellitus.

\section{Acknowledgments}

We thank Dr. J. Furrer for allowing us to study two of his patients; Dr. P. Holzmann, Ms. S. Graf, Ms. Y. Glatz, and Mr. A. Lenz for technical assistance; and Ms. S. Vosmeer and Dr. U. Keller for the determination of glucagon levels. The help of the nurses on the metabolic ward is highly appreciated.

This work was supported by the Swiss National Science Foundation (grant 31-9095.87) and by Ciba-Geigy AG (Basel, Switzerland).

\section{References}

1. Campbell, P. J., L. J. Mandarino, and J. E. Gerich. 1988. Quantification of the relative impairment in actions of insulin on hepatic glucose production and peripheral glucose uptake in non-insulin-dependent diabetes mellitus. Metab. Clin. Exp. 37:15-21.

2. DeFronzo. 1988. The triumvirate: $\beta$-cells, muscle, liver. A collusion responsible for NIDDM. Diabetes. 37:667-687.

3. Porte, D, Jr. 1991. $\beta$-cells in type II diabetes mellitus. Diabetes. 40:166180.

4. DeFronzo, R. A., V. Soman, F. S. Sherwin, R. Hendler, and P. Felig. 1978. Insulin binding to monocytes and insulin action in human obesity, starvation, and refeeding. J. Clin. Invest. 62:204-213.

5. Arsenis, G., and J. N. Livingston. 1986. Alterations in the tyrosine kinase activity of the insulin receptor produced by in vivo hyperinsulinemia. J. Biol. Chem. 261:147-153.

6. Livingston, N., T. Pollare, H. Lithell, and P. Arner. 1988. Characterisation of insulin-like growth factor I receptor in skeletal muscles of normal and insulin resistant subjects. Diabetologia. 31:871-877.

7. Rossetti, L., D. Smith, G. I. Shulman, D. Papachristou, and R. A. DeFronzo. 1987. Correction of hyperglycemia with phlorizin normalizes tissue sensitivity to insulin in diabetic rats. J. Clin. Invest. 79:1510-1515.

8. Ferrannini, E., S. M. Haffner, B. D. Mitchell, and M. P. Stern. 1991. Hyperinsulinaemia: the key feature of a cardiovascular and metabolic syndrome. Diabetologia. 34:416-422.

9. Fontbonne, A. M., and E. M. Eschwège. 1991. Insulin and cardiovascular disease. Paris prospective study. Diabetes Care. 14:461-469.

10. Jarrett, R. J., P. McCartney, and H. Keen. 1982. The Bedford survey: ten year mortality rates in newly diagnosed diabetics and normoglycaemic controls and risk indices for coronary heart disease in borderline diabetics. Diabetologia. 22:79-84.

11. Juhan-Vague, I., C. Roul, M. C. Alessi, J. P. Ardissone, M. Heim, and P. Vague. 1989. Increased plasminogen activator inhibitor activity in non insulin dependent diabetic patients-relationship with plasma insulin. Thromb. Haemostasis. 61:370-373.

12. Henry, R. R., P. Wallace, and J. M. Olefsky. 1986. Effects of weight loss on mechanisms of hyperglycemia in obese non-insulin-dependent diabetes mellitus. Diabetes. 35:990-998.

13. Barakat, H. A., J. W. Carpenter, V. D. McLendon, P. Khazanie, N. Leggett, J. Heath, and R. Marks. 1990. Influence of obesity, impaired glucose tolerance, and NIDDM on LDL structure and composition. Possible links between hyperinsulinemia and atherosclerosis. Diabetes. 39:1527-1533.

14. Firth, R., P. Bell, M. Marsh, and R. A. Rizza. 1987. Effects of tolazamide and exogenous insulin on pattern of postprandial carbohydrate metabolism in patients with non-insulin-dependent diabetes mellitus. Results of randomized crossover trial. Diabetes. 36:1130-1138.

15. Rizza, R. A., L. J. Mandarino, J. Genest, B. A. Baker, and J. E. Gerich. 1985. Production of insulin resistance by hyperinsulinemia in man. Diabetologia. 28:70-75.

16. Gutniak, M., S.-G. Karlander, and S. Efendic. 1987. Glyburide decreases insulin requirement, increases $\beta$-cell response to mixed meal, and does not affect insulin sensitivity: effects of short- and long-term combined treatment in secondary failure to sulfonylurea. Diabetes Care. 10:545-554.

17. Glaser, B., G. Leibovich, R. Nesher, S. Hartling, C. Binder, and E. Cerasi. 1988. Improved beta-cell function after intensive insulin treatment in severe non-insulin-dependent diabetes. Acta Endocrinol. 118:365-373.

18. Poggi, C., Y. Le Marchand-Brustel, J. Zapf, E. R. Froesch, and P. Freychet. 1979. Effects and binding of insulin-like growth factor in the isolated soleus muscle of lean and obese mice: comparison with insulin. Endocrinology. 195:723-730.

19. Sinha, M. K., C. Buchanan, N. Leggett, L. Martin, P. G. Khazanie, R DiMarchi, W. J. Pories, and J. F. Caro. 1989. Mechanism of IGF-I-stimulated glucose transport in human adipocytes. Demonstration of specific IGF-I receptors not involved in stimulation of glucose transport. Diabetes. 38:1217-1225.

20. Guler, H. P., J. Zapf, and E. R. Froesch. 1987. Short-term metabolic effects of recombinant human insulin-like growth factor $\mathrm{I}$ in healthy adults. $N$. Engl. J. Med. 317:137-140.

21. Zenobi, P. D., H. P. Guler, J. Zapf, and E. R. Froesch. 1988. Insulin-like growth factors in the Göttinger miniature-pig. Acta Endocrinol. 117:343-352.

22. Schoenle, E. J., P. D. Zenobi, T. Torresani, E. A. Werder, M. Zachmann, and E. R. Froesch. 1991. Recombinant human insulin-like growth factor I (rhIGF I) reduces hyperglycaemia in patients with extreme insulin resistance. Diabetologia. 34:675-679. 
23. Jacob R., E. Barrett, G. Plewe, K. D. Fagin, and R. S. Sherwin. 1989. Acute effects of insulin-like growth factor I on glucose and amino acid metabolism in the awake fasted rat. Comparison with insulin. J. Clin. Invest. 83:17171723.

24. Jacob, R. J., R. S. Sherwin, L. Bowen, D. Fryburg, K. D. Fagin, W. V. Tamborlane, and G. I. Shulman. 1991. Metabolic effects of IGF-I and insulin in spontaneously diabetic BB/w rats. Am. J. Physiol. 260:E262-E268.

25. Rossetti, L., S. Frontoni, R. Dimarchi, R. A. DeFronzo, and A. Giaccari. 1991. Metabolic effects of IGF-I in diabetic rats. Diabetes. 40:444-448.

26. Zenobi, P. D., S. Graf, H. Ursprung, and E. R. Froesch. 1992. Effects of insulin-like growth factor-I on glucose tolerance, insulin levels, and insulin secretion in healthy man. J. Clin. Invest. 89:1908-1913.

27. Zenobi, P. D., S. Graf, A. Thut, W. Riesen, and E. R. Froesch. 1991. Effects of recombinant human insulin-like growth factor-I (rhIGF-I) infusions on glucose and lipid metabolism in healthy man. Int. Mtg on Somatomedins/IGFs, 2nd, San Francisco. D4. (Abstr.)

28. Leahy, J. L., and K. M. Vandekerkhove. 1990. Insulin-like growth factor-I at physiological concentrations is a potent inhibitor of insulin secretion. Endocrinology. 126:1593-1598.

29. Guler, H. P., C. Schmid, J. Zapf, and E. R. Froesch. 1989. Effects of recombinant insulin-like growth factor I on insulin secretion and renal function in normal human subjects. Proc. Natl. Acad. Sci. USA. 86:2868-2872.

30. Walker, J. L., M. Ginalska-Malinowska, T. E. Romer, J. B. Pucilowska, and L. E. Underwood. 1991. Effects of the infusion of insulin-like growth factor I in a child with growth hormone insensitivity syndrome (Laron dwarfism). $N$. Engl. J. Med. 324:1483-1488.

31. Hartling, S. G., B. Dinesen, A. M. Kappelgard, O. K. Faber, and C. Binder. 1986. ELISA for human proinsulin. Clin. Chim. Acta. 156:289-298.

32. Aguilar-Parada, E., A. M. Eisentraut, and R. H. Unger. 1969. Pancreatic glucagon secretion in normal and diabetic subjects. Am. J. Med. Sci. 257:415419.

33. Feek, C. M., J. S. Bevan, S. Taylor, N. S. Brown, and J. D. Baird. 1981 The effect of bromocriptine on insulin secretion and glucose tolerance in patients with acromegaly. Clin. Endocrinol. 15:473-478.

34. Baxter, R. C., and J. L. Martin. 1986. Radioimmunoassay of growth hormone dependent insulin-like growth factor binding protein in human plasma. J. Clin. Invest. 78:1504-1512.

35. Sönksen, P. H., F. C. Greenwood, J. P. Ellis, C. Lowy, A. Rutherford, and J. D. N. Nabarro. 1967. Changes of carbohydrate tolerance in acromegaly with progress of the disease and in response to treatment. J. Clin. Endocrinol. 27:14181430.

36. Zapf, J., C. Schmid, H. P. Guler, M. Waldvogel, C. Hauri, E. Futo, P. Hossenlopp, M. Binoux, and E. R. Froesch. 1990. Regulation of binding proteins for insulin-like growth factors (IGF) in humans. J. Clin. Invest. 86:952-961

37. Suikkari, A. M., V. A. Koivisto, R. Koistinen, M. Seppälä, and H. YkiJärvinen. 1989. Dose-response characteristics for suppression of low molecular weight plasma insulin-like growth factor-binding protein by insulin. J. Clin. Endocrinol. \& Metab. 68:135-140.
38. Snyder, D. K., and D. R. Clemmons. 1990. Insulin-dependent regulation of insulin-like growth factor-binding protein-1. J. Clin. Endocrinol. \& Metab. 71:1632-1636.

39. Guler, H. P., J. Zapf, C. Schmid, and E. R. Froesch. 1989. Insulin-like growth factors I and II in healthy man. Estimations of half-lives and production rates. Acta Endocrinol. 121:753-758.

40. Bar, R. S., D. R. Clemmons, M. Boes, W. H. Busby, B. A. Booth, B. L. Dake, and A. Sandra. 1990. Transcapillary permeability and subendothelial distribution of endothelial and amniotic fluid insulin-like growth factor binding proteins in the rat heart. Endocrinology. 127:1078-1086.

41. White, R. M., S. P. Nissley, A. C. Moses, M. M. Rechler, and R. E. Johnsonbaugh. 1981. The growth hormone dependence of a somatomedin-binding protein in human serum. J. Clin. Endocrinol. \& Metab. 53:49-57.

42. Hardouin, S., M. Gourmelen, P. Noguiez, D. Seurin, M. Roghani, Y. Le Bouc, G. Povoa, T. J. Merimee, P. Hossenlopp, and M. Binoux. 1989. Molecular forms of serum insulin-like growth factor (IGF)-binding proteins in man: relationships with growth hormone and IGFs and physiological significance. J. Clin. Endocrinol. \& Metab. 69:1291-1301.

43. Froesch, E. R., H. P. Guler, C. Schmid, M. Ernst, P. D. Zenobi, and J. Zapf. 1989. Growth promotion by insulin-like growth factor I: endocrine and autocrine regulation. In Auxology 88. Perspectives in the Science and Growth and Development. J. M. Tanner, editor. Smith-Gordon, London. 251-263.

44. Olefsky, J. M., and O. G. Koltermann. 1981. Mechanisms of insulin resistance in obesity and noninsulin-dependent (type II) diabetes. Am. J. Med. 70:151-168.

45. Steiner, G., S. Morita, and M. Vranic. 1980. Resistance to insulin but not to glucagon in lean human hypertriglyceridemics. Diabetes. 29:899-905.

46. Grant, M. B., C. Guay, and R. Marsh. 1990. Insulin-like growth factor I stimulates proliferation, migration, and plasminogen activator release by human retinal epithelial cells. Curr. Eye Res. 9:323-335.

47. Bornfeldt, K. E., R. A. Gidlöf, A. Wasteson, M. Lake, A. Skottner, and H. J. Arnqvist. 1991. Binding and biological effects of insulin, insulin analogues and insulin-like growth factors in rat aortic smooth muscle cells. Comparison of maximal growth promoting activities. Diabetologia. 34:307-313.

48. Dills, D. G., S. E. Moss, R. Klein, and B. E. K. Klein. 1991. Association of elevated IGF-I levels with increased retinopathy in late-onset diabetes. Diabetes. 40:1725-1730.

49. Dills, D. G., S. E. Moss, R. Klein, B. E. K. Klein, and M. Davis. 1990. Is insulinlike growth factor I associated with diabetic retinopathy? Diabetes. 39:191-195.

50. Lamberton, R. P., A. D. Goodman, A. Kassoff, C. L. Rubin, D. H. Treble, T. M. Saba, T. J. Merimee, and W. J. Dodds. 1984. Von Willebrand factor (VIII $\mathrm{R}: \mathrm{Ag})$, fibronectin, and insulin-like growth factors I and II in diabetic retinopathy and nephropathy. Diabetes. 33:125-129.

51. Rymaszewski, Z., R. M. Cohen, and P. Chomczynski. 1991. Human growth hormone stimulates proliferation of human retinal microvascular endothelial cells in vitro. Proc. Natl. Acad. Sci. USA. 88:617-621. 